\title{
The Transatlantic Dialogue on Iran: The European Subaltern and Hegemonic Constraints in the Implementation of the 2015 Nuclear Agreement with Iran
}

\begin{abstract}
This article analyses the US-EU transatlantic dialogue on the Iranian nuclear dossier with a particular view to implications for European Union (EU) foreign policy on Iran. Doing so, it uses neo-Gramscian scholarship to put the EU's 'over-compliance' with Iran sanctions into perspective. Constrained by the imperatives of hegemonic coercion in the form of US financial Iran sanctions against third country entities and with the hegemonic consent of a Western US-led 'historic bloc', Europe was relegated to a subaltern below its mediatory potential. It will be shown how this finding complicates the EU's ambition to renew relations with Iran. Drawing on semi-structured interviews with experts and delegation members from the $\mathrm{P} 5+1$, this article thus analyses 'the normative element' in the transatlantic security dialogue on Iran at a time where the latter is undergoing a sea change in the wake of the implementation of the 'Joint Comprehensive Plan of Action' of July 2015.
\end{abstract}

Keywords: Iranian Nuclear Programme, EU Diplomacy, US Foreign Policy, Critical Security Studies, Hegemony, Nuclear Diplomacy 


\section{Introduction}

On 16 January 2016, all UN, EU, and US nuclear-related sanctions on Iran were lifted after the confirmation by the International Atomic Energy Agency (IAEA) that Iran had fulfilled its commitments of the nuclear agreement reached in July 2015 (IAEA, 2016). This marked the 'Implementation Day' - in the agreement's parlance - of the Joint Comprehensive Plan of Action (JCPOA) to resolve the stand-off on the controversial Iranian nuclear programme that has bedeviled international politics ever since its discovery in 2002. The US and EU administrations initiated the lifting of sanctions specified in Annex V of the JCPOA, while relevant sanctions provisions in UN Security Council Resolutions (UNSCR) 1696, 1737, 1803, 1835, 1929 and 2224 were terminated. ${ }^{1}$ This in itself is a historic success of international diplomacy to prevent war in the Middle East, and the first successful precedent for the rewinding of UN sanctions imposed over proliferation charges without resorting to military means or regime change plans. The verified rollback of nuclear capabilities is also rare in arms-control history (Fitzpatrick, 2016).

With nuclear-related UN-mandated sanctions and those adopted by the EU and the US administration lifted, the path is cleared for an altered engagement of Iran with the world. European businesses are eager to see the latter scenario bring renewed investment opportunities. EU High Representative Federica Mogherini travelled to Tehran in April 2016 to emphasise the importance of the speedy implementation of the 
JCPOA. She was accompanied by business representatives as well as seven EU commissioners, signaling a high-level interest on the part of the EU in re-entering the Iranian market. But the evolution of the EU-US dialogue on the Iranian nuclear conflict has seen the adoption of policy choices on the part of the EU that were promoted and favored by US administrations. These put the EU into an intricate position with regard to future Iran policies. Most notoriously, the extraterritorial nature of US unilateral sanctions has relegated the EU to an entity constrained in autonomous Iran policy formulation in the complex nuclear diplomacy with Iran. After 2010, in addition, the EU adopted its own Iran sanctions that were modeled on American legislation and went well beyond UN provisions. European governments have subscribed to normative readings of security that were formulated not in Europe, but in Washington. This confronts us with a paradox: Ushering in a 'new chapter' in relations with Iran that Mogherini spoke about after the conclusion of the nuclear agreement (EEAS, 2015) will require the disentanglement of EU Iran policies from US policy preferences at a time where both the EU and the US take an active part in the implementation of the JCPOA. This article proceeds to examine this paradox in its impact on EU foreign policy on Iran. Doing so, it will draw on neo-Gramscian scholarship (Cox, 1981; 1996; Jones, 2006; Worth, 2009; 2011) to show how Europe faces structural constraints for any reformulation of its future Iran policies after the nuclear agreement. The article posits that conceptualisations of the EU-US security dialogue have traditionally been steeped 
in rationalist frameworks (Kotzias and Liacouras, 2006; Rees, 2011; Menotti and Vencato, 2008; Toje, 2008) that fail to account for the inherently relational aspect of international politics and the normative power of order-constituting discourses (on the latter, cf. Homolar, 2011; Hoyt, 2000; Senn, 2009). The acceptance or rejection of a foreign policy behaviour as appropriate is the expression of security cultures. 'Security' becomes situational and is intimately and inextricably linked with images of 'Self' and 'Other'. The social construction of identities and 'order' is intimately linked with hegemonic legitimacy, and it is here that neo-Gramscian scholarship offers a useful lense to understand the intertwining of security perceptions, role expectations, and identity politics - factors in foreign policy perennially missed in realist and liberalinstitutionalist approaches. In Gramsci's understanding of hegemony, a dominant class forms a relationship with subaltern classes that is characterised both by consent and coercion (Gramsci, 1971: 55-60; 415-25). Such an ensemble of and arrangement between hegemonic structures and the wider society represents a 'historic bloc'. In a neo-Gramscian understanding of hegemony in International Relations as developed, e.g., in Cox's seminal works on World Order (Cox, 1996: 131), the prevalence of dominant structures that are accepted and sustained by a sufficiently large number of other actors (states) can also constitute such a 'historic bloc'. Force and coercion, Gramsci has further theorised, can never alone sustain a historic bloc, but must be complemented by a level of (tacit) consent between hegemonic structures and 
subalterns. In International Relations Theories, this nuances the idea that hegemony is necessarily an endeavor driven by a dominant state in that the interactions between the forces of consent and coercion and between different levels collectively serve to perpetuate hegemonic structures. Rather than conceiving of the mechanisms of hegemony as one-dimensional economic coercion, this dual face of dominance helps us understand how hegemony establishes itself also on an ideational level. This article will demonstrate how such a neo-Gramscian conceptualisation can fruitfully be applied to the EU-US dialogue on Iran and tensions over diverging priorities in the implementation of the JCPOA. It will be shown how neo-Gramscian scholarship offers an under-utilised conceptual angle to US-EU relations in general, and how the Iran case serves as an illustrative application in particular for a Gramscian conception of hegemony in international relations. Such an approach has never been used to analyse the US-EU dialogue on Iran before. The implementation of the nuclear agreement can entail a European emancipation from a hegemonic narrative that has been woven over decades of institutionalised enmity. While 'emancipation' has become somewhat of a buzzword in Critical Theories, it is here defined as the contestation of such dominant narratives and their policy implications (e.g. extraterritorial sanctions) that allows for the formulation of autonomous policies. In other words, it captures the extent of agency of the EU.

The article proceeds as follow. A first section briefly process-traces the 
evolution of the EU as an actor and mediator in Iran diplomacy, and how the transatlantic dialogue on the Iran nuclear case unfolded. Process-tracing is used here in its outcome-oriented variant that aims to understand decisional processes (Beach \& Pedersen, 2013: 3). A second section then illustrates how US financial and structural power has meant that the United States would become the single most influential actor in not only shaping the Iran nuclear talks, but in setting the tone for the transatlantic dialogue on Iran as well. It will be shown how the EU has responded by 'overcomplying' with US policy preferences in general, and US unilateral Iran sanctions in particular. A third section outlines the potential and risks associated with the implementation of the nuclear agreement reached on 14 July 2015 with regard to the transatlantic dialogue on Iran. European emancipation in its Iran policies, it will be shown, is conditioned on the faithful implementation of the deal and the crafting of genuine European policies on Iran and the Middle East. The research methods used are qualitative document analysis and process-tracing, complemented by semi-structured elite interviews that were conducted for the purpose of this study. Interviewees included current and former officials with expert knowledge of the EU and US Iran policy decision-making processes.

\section{European Iran Diplomacy: From Resistance to Subaltern Relegation}

In the absence of US-Iranian bilateral relations, it fell to the 'E3' (i.e. France, United Kingdom and Germany) to lead negotiations with Iran when the latter's nuclear 
programme was uncovered in 2002 . The choice was arbitrary and reflected a traditional understanding of the weight of the 'Big Three' in intra-EU power arrangements (Patrikarakos, 2012: 196). The format of the 'E3' was joined by the EU High Representative for the Union's Common and Security Policy (CFSP), Javier Solana at the time, in late $2003 .^{2}$ While the foreign policies of Germany, France, and the UK in the Iran dossier have partially been very different, the 'E3', an essentially ad hoc and extra-CFSP mechanism created by crisis management, gradually became accepted as an indicator for an EU-wide approximation of positions on the Iran nuclear issue. ${ }^{3}$ The EU had a history of engagement with the Islamic Republic of Iran, dating back to the phases of 'critical dialogue' and 'constructive dialogue' during the Rafsanjani administration. The diplomatic track record of the E3 in negotiations after 2003 concerning the Iranian nuclear programme has been widely analysed in the scholarly literature as well as in memoirs and biographies of decision-makers. ${ }^{4}$ The aim here is thus not to revisit the evolution of the EU as a policy actor in the Iran talks, but to highlight when and how its presence as an actor shifted from having a mediatory capacity to subscribing to a punitive unified 'bloc' position with the US. For the purpose of this article, this is an important conceptual first step in analysing the intertwining of the forces of consent and coercion in the US-EU dialogue on Iran.

Under the E3's negotiation efforts, nuclear talks seemed to have been making progress since the stalled 2003 Sa'dabad negotiations all the way to the initially 
applauded 2004 Paris agreement, which outlined broad-based European-Iranian cooperation in a number of issue areas, including comprehensive cooperation in the nuclear, technological and economic field in return for 'objective guarantees' in the exclusively peaceful nature of the Iranian nuclear programme. The Iranian perception of the EU was that of a more impartial balancer to the aggressive stance of the Bush administration at the time (Mousavian, 2012: 152-156; 175-179). "[I]n Iran's view," Mousavian sums up the Iranian perspective in his memoir of the Iranian nuclear crisis, "the [E3-Iran] Paris agreement amounted to a refutation of claims raised by the American bloc that Iran posed a threat to world peace" (Mousavian, 2012: 152). The E3's diplomatic initiative deserves credit for laying out conditions for diplomatic compromises that would later serve as a basis for negotiations in the extended E $3+3$ format (Alcaro \& Tabrizi, 2014: 16). The US position at the time uncompromisingly insisted on the complete dismantling of Iranian nuclear facilities and 'zero enrichment' (Patrikarakos, 2012: 197). In this early phase of nuclear diplomacy, at least until the November 2004 agreement, the Europeans' negotiating credibility lay in their potential to block the Americans from pushing the case to be referred to the Security Council and in serving as a 'human shield' against possible American or Israeli unilateral attacks on Iranian nuclear facilities (Porter, 2014: 141; Mousavian, 2012: 103). Structurally, the non-inclusion of the US in the nuclear talks, combined with US opposition to EU diplomacy, diminished the EU's mediatory leeway. ${ }^{5}$ Had the US been sitting at the table 
from the outset, Iran would have likely faced tougher Western $(E 3+1)$ negotiating positions, but would also have known that the talks enjoyed the backing of the administration in Washington. The Iranian presidential election in 2005 that saw the coming into office of president Ahmadinejad then meant a turn for the worse concerning cooperation with the West. Developments as from 2005 accounted for a failure of the early EU-led proposals and the eventual referral of the Iranian nuclear dossier from the IAEA Board of Governors to the United Nations Security Council (UNSC) according to Art. XII.C of the IAEA Statute after Iran had resumed previously suspended uranium enrichment in August 2005. It is at this juncture that hopes for easily negotiable solutions were dashed. Taylor (2010) notes that after 2004, a deal was struck between Brussels and Washington whereby 'the Europeans would acquiesce to the use of sanctions provided that the Americans joined the incentives package' (99).

The referral to the Security Council in February 2006 by an IAEA board vote of 27-3 paved the way for the eventual imposition of Chapter VII sanctions on Iran and, interestingly, a gradual shift of positions within the 'Western' camp, with France and the UK becoming increasingly more assertive and formulating confrontational foreign policy stances on Iran, to an extent even that leads Oborne and Morrison (2013) to describe them as 'client states' of the US in the Iran dossier (6). '[...] the quality of its (Europe's) acting has decreased as a new protagonist, the US, has gradually, but inexorably, stolen the limelight', Alcaro and Tabrizi (2014: 15) put it. A former 
European ambassador to Tehran quipped in an interview: 'The Iranians go back to Tehran and the Supreme Leader says No to our [European] package. But we have our own Supreme Leader in Washington' (Author's interview, London, 15 September 2016). European Iran diplomacy now followed what was called a 'dual-track approach' between pressure and engagement. To observers, this was reminiscent of the US talk of 'carrots and sticks'. Kayhan Barzegar (2012) attests a loss of the EU's 'independent and mediatory role in the Iranian nuclear dossier' after the failed 2004 Paris agreement, and observes a closer alignment with US positions thereafter, 'adopting principles of deterrence and anti-weaponization' (256). The actors calling for moderation and voicing scepticism about the use of sanctions had now become Russia and China in the extended E3+3 format. In its implementation of UNSC Iran sanctions, such as UNSCR 1737 in 2007 or UNSCR 1803 in 2008, the EU went beyond UN provisions and listed additional individuals and entities and froze Iran's Bank Melli's assets and subsidiaries (Taylor, 2010: 75-77). While such listings of individuals can be seen as largely symbolic sanctions, the real sea change in EU Iran sanctions came in 2010. With Council Regulation 961, the EU adopted its own sanctions that went well beyond the UNSC-backed international sanctions on Iran and arguably affected Iranian entities and Iran's economy much more than US unilateral sanctions (EU Council, 2010). ${ }^{6}$ With this decision, a policy shift was introduced in the EU Foreign Affairs Council (FAC), whereby the 'targeted' approach of EU sanctions, reflecting a sceptical view of 
economic pressure, was being replaced by a comprehensive sanctions regime (Tabrizi, 2014: 2). '[S]een as central for the success of the American coercive approach, [...] US under secretary of Treasury Stuart Levy pressured the EU to impose sanctions framed on the US unilateral legislation, the CISADA', as Tabrizi and Santini $(2012,2)$ write. The significance of US unilateral legislation will be examined in the next section. It is important to retain here, however, that key EU member states had adapted their positions to allow for the imposition of far-reaching European sanctions modeled on American ones. Alcaro and Tabrizi trace such a level of cohesion 'back to European alignment with US policy rather than to EU-US policy convergence', referring to 'alignment' as a conscious decision to 'follow the US lead' (2014: 18). In 2012, the EU then moved to a complete freeze of its trade with Iran in the energy sector: While in November 2011, the UK had been the only EU member state to unilaterally impose an oil embargo on Iran (Tabrizi \& Santini, 2012: 2), such a step became a policy consensus half a year later: In July 2012, the Council adopted an EU oil embargo on Iran. This came after its decision in March to disconnect Iranian banks from the SWIFT banking system (EU Council, 2012b). With this decision at the latest, the EU ceased to be a balancer against US positions, as seen by Tehran. Former Iranian official Mousavian writes in his 2014 book (37): 'One of the harshest blows to the Iranian financial system came with the US Congress threatening to place sanctions on the Belgian-based Society for Worldwide International Financial Telecommunication (SWIFT) unless they cut ties 
with all Iranian banks. [...] Unsurprisingly, the EU yielded to US threats and consequently cut off the Iranian Central Bank from the international financial system' (38).

The ensuing oil embargo has been likened to an 'ice-breaker' lowering 'resistance to further sanctions decisions' (Lehne, 2012). A gas embargo followed suit in October 2012. Additional sanctions included a ban on the trade of diamonds and precious metals, the banning of European companies from providing insurance for oil or petrochemical shipments from Iran, the banning of transactions between European and Iranian banks, and the freezing of assets of the Iranian Central Bank held within the EU (EU Council, 2012a; 2012b; 2012c). Dupont argues that the lawfulness of these 'restrictive measures' (in the EU's own terminology) is dubious under international law, as these were countermeasures taken by a regional organization that go beyond UNSC sanctions taken pursuant to Chapter VII (Dupont, 2012). It is important to note that these were deliberate EU policy decisions. EU Iran sanctions have seen a qualitative change from 2010 onwards, as opposed to the human rights-related sanctions adopted in the 1990s. ${ }^{7}$ Adverse economic consequences of Iran sanctions regimes, given traditionally substantial EU-Iranian economic relations, were therefore not only the outcome of the extraterritorial application of US legislation - the latter of which will be dealt with in the next section. Instead, the January-October 2012 new round of EU sanctions has to be considered a turning point for a change of mindset of European 
policymakers that made EU Iran policy more compatible with the US approach. Between the US and the EU, there now was a close collaboration on the areas targeted by their respective unilateral sanctions so as to maximise their effect. 'This makes it not the UN, but as multilateral as possible,' an E3 delegation member remarked (Author's interview, Brussels, 24 February 2015). Another E3 official put this as follows:

'We coordinated with the US before every round of sanctions. This has a political effect: You want to maximise the shock effect. If you want to shock the market, if you want to bankrupt a country, (and) if you do it yourself, it takes a hell of a lot of time' (Author's interview, London, 10 March 2015). ${ }^{8}$

Another European diplomat explains the EU rationale to follow suit in an interview as follows:

'Europe was under serious pressure. But we are part of the $3+3$ format. The Americans like to impose sanctions, but have little trade with Iran. So they are looking at their partners to put pressure on Iran. It was only logical that we followed suit' (Author's interview, Brussels, 6 February 2015).

Thus confronted with a 'Western' bloc position of pressure, the Ahmadinejad administration put more emphasis on its policy of 'looking to the East' in order to diversify Iranian trade relations so as to better resist US pressure (Mousavian, 2012: 
190f.).

A 'historic bloc', in Gramsci's terminology, triggers counter-hegemonic ambitions to subvert that bloc's power status. Iran's 'looking to the East' policy, however, was met with little enthusiasm in Russia and China, as testified by their votes in favor of international sanctions on Iran from 2006 onwards. Since 2006 and the formation of the P5+1, the term 'Western camp' was referred to in order to differentiate between the Western (Germany, France, UK, USA) and non-Western (China, Russia) state parties in this negotiation format. The inclusion of China and Russia was deemed crucial to dispel the reading that 'the West' was aiming to deprive Iran of legitimate rights. Yet, Russia and China critiqued the rhetoric of the US and some EU delegations as concerns Iranian intentions, and sought to balance between upholding good relations with Iran, braking the Western push for sanctions, and displaying a willingness to accommodate US concerns (Pieper, 2014). In their analysis of the approaches of 'rising powers' to non-proliferation sanctions, Biersteker and Moret (2015) find ambivalence in the positions of Russia and China, but also of other 'emerging' powers such as India, Brazil, Turkey and Indonesia: While they have not systematically opposed the adoption of UN sanctions, they have criticized their intrusive nature, but have supported them on some occasions (see also Pieper, 2017). This finding reinforces the idea in Gramscian Thought that the positions within a prevalent historic bloc, its subalterns and counterhegemonic forces are reacting to each other and are thus constantly subject to change 
and re-negotiation (Jones, 2006: 79). It is at this point of re-negotiation of policies that counter-hegemonic movements have their biggest leverage. 'New powers', however, rarely articulate radical alternatives to existing orders (Narlikar, 2013: 575). Historic blocs change gradually, subject to socialization and the framing of particular demands. In this process, Narlikar singles out the EU and the US as 'gatekeepers to the inner sanctums of international regimes', as 'the chief established powers of today' (Narlikar, 2013: 563). Diverging positions between the US and the EU administrations in the early years of nuclear diplomacy with Iran therefore gave Tehran ample opportunities to 'exploit the gap between Europe and the United States to achieve Iranian objectives', as Mousavian (2012: 180) confirms. With the EU's imposition of biting unilateral sanctions and its acquiescence concerning the extraterritorial application of US financial sanctions that the next section will expand on, however, a Western consent regarding a unified bloc position on Iran was achieved by 2012. What in diplomatic circles was referred to as 'P5+1 unity' was meant to prevent Iran from playing off one delegation against another. A French delegation member to the nuclear talks recalls how 'We first discuss within the E3+1, then we go to Russia and China, who add their own views, then we have meetings with Iran. Russia, for example, would tell us at the E3+3 level that we [the E3+1] are going too far with a certain proposition, but that they wouldn't say so at the talks with Iran in order to keep the "P5 unity" (Author's interview, Vienna, 18 August 2016). Had this strife for 'unity' not existed, European delegations 
would have retained more room for maneuver in their negotiating positions, but at the expense of strengthening Iran's hand in the talks. Noticeably, as shown above, 'E3+1' joint approaches were facilitated by a growing convergence in sanctions matters as from 2012. A Gramscian conceptual angle puts such a behaviour into perspective: In what Gramsci calls a 'hegemonic bloc', powerful actors mould a consensual order that is based on the interacting forces of consent and coercion (Gramsci, 1971: 55-60; 415-25; Cox, 1996: 131). Coercion alone cannot sustain such a 'hegemonic bloc', but has to be complemented by consent, by conventionally accepted standards of appropriate behaviour. Hegemony here is thus not solely understood as the exercise of power by one dominant nation-state, but by a self-reinforcing logic of transnational consensus. William Robinson, in his 1996 Promoting Polyarchy, similarly argues that 'structures of asymmetry in the international political economy are sustained and international relations of power and domination exercised through variants of coercive or consensual mechanisms of transnational social control' (23). While hegemonic structures can be inspired and promoted by strong states, their persistence depends on the sharing of an underlying logic across what in orthodox power analyses are the dominant and the dominated. The 'values of the power bloc, subalterns and counter-hegemonic forces are in a constant state of negotiation, compromise and change', Jones (2006: 79) reminds us. US 'allies', in this understanding, are 'subalterns' that subscribe to the hegemonic projects of such a power bloc (Jones, 2006: 42). Critical of US unilateral attempts to 
sanction Iran that increasingly also affected Iranian-European trade relations ('secondary sanctions') in the 1990s, the EU's stance on unilateral sanctions has been such that an initial criticism has led to an 'over-compliance' from 2010 onwards. So while 'resistance' can and does take place within a historic bloc, and even between hegemonic forces and 'subalterns', the track record of European Iran diplomacies suggests the conclusion that despite differences in policy preferences, the EU has fully subscribed to hegemonic structures. ${ }^{9}$ This has created the necessary consent of 'subalterns' to sustain and reinforce hegemonic constellations. Similarly, in their case study of the EU's Common Security and Defence Policy as 'an act of American hegemony', Kempin \& Mawdsley find that 'US strategic domination of Western Europe was not by force but by invitation' (2013: 58). In hegemonic arrangements, in other words, dominant actors convince others of the need to sustain the current order not only by way of penalties in case of non-compliance, but by co-opting them with compelling narratives.

In such arrangements, the power of exclusionary logic, i.e. thought patterns that exclude possible alternatives, has a strong normative pull. 'The most effective sanctions are those that are not written', a European Iran desk officer explained, 'there is a moral suasion; an international mood where you could not have any cooperation with Iran because of US pressure. You could not even have dared to export spaghetti to Iran' (Author's interview, Rome, 8 August 2016). 
Another actor's (US) expectancy is being internalised here and structures European decision-making. ${ }^{10}$ Coercion and consent served to build a hegemonic stance, on both a material (economic and financial sanctions) and an ideational (shift in positions in the FAC) level. 'We made a sacrifice once', an EEAS official who was involved in the nuclear negotiations explained, 'we had a lot of trade with Iran, but we voluntarily scaled it back and imposed an oil embargo. Such things are political commitments.' (Author's interview, Brussels, 15 April 2016). The result was a transatlantic Iran diplomacy long favored by Washington. Reversing its stance on Iran sanctions from a decade before, Europe thus relegated itself to the role of a 'subaltern' in a hegemonic power constellation. This finding, however, is not to rule out the plausibility of European leaders deciding on the necessity of stronger sanctions for their own ends, and different policy preferences are spread across national bureaucracies as well. While the UK and France were the strongest advocates of tough sanctions, other member states like Austria, Germany, Italy and Spain were more sceptical. Such differences have inevitably shaped the nature and scope of the EU's measures. The EU also has adopted restrictive measures elsewhere. EU Russia, Syria, or Libya sanctions all have their respective rationales and contexts, and it is not argued here that all EU sanctions are adopted to 'appease' the US. Yet, reflections of involved desk officers in the Iran case reveal a level of awareness that EU 'restrictive measures' against Iran after 
2010 were responding to a political momentum generated elsewhere. The next section will qualify the nature thereof.

\section{The Power of Consent and Coercion in Iran Diplomacy}

'Hegemonic strategies [...],' former US National Security Council officials Leverett \& Leverett (2013) write, 'are inherently expansionist: a state uses military, political, and economic power not just to defend its interests but to bend others into accommodating them' (332). The US here is deemed a single most dominant actor that, as of yet, remains unmatched in its potential to influence other actors through such hegemonic structures (cf. also Wilkinson, 1999: 142; Krahmann, 2005: 533; Wicht, 2002: 77; Hart \& Jones, 2011; Quinn, 2011; Stokes, 2014; Cox, 2001; 2007).

It was the United States that shaped a narrative of Iran that has had a determining impact on the formulation of the Iran policies of other Western governments. The US unilateral sanctions regime on Iran is arguably the most significant indication thereof: the US imposed punitive measures onto other states that do business with Iran (Lohmann, 2013) - an 'imperial extension of American power and $[\ldots]$ (a) sheer effrontery by which America sought to impose its political position', as Ali Ansari (2006: 144) puts it. The first effort to sanction third country entities engaging with Iran was enacted with the 1992 Iran-Iraq Nonproliferation Act that prohibited the transfer of goods or technologies that could facilitate the development of 
ABC weapons (Takeyh \& Maloney, 2011: 1301). ${ }^{11}$ This sector-specific sanctions regime was significantly expanded with the Iran-Libya Sanctions Act (ILSA) of 1996, which was modified in 2001 and renamed the Iran Sanctions Act in 2006 (Leverett \& Leverett, 2013: 310). Beyond the initial proliferation dimension, the ILSA imposed sanctions on third country entities investing more than 40 million US dollars in the development of petroleum resources in Iran. This extension of the scope and applicability of Iran sanctions signified a sea change in US Iran policies in the way these gradually served to create a regime that moved away from targeting specific individuals and sectors to an all-encompassing one that was to be adhered to on a global basis. The extraterritorial application of these US unilateral sanctions was introduced with the justification of 'Iranian sponsoring of international terrorism', and thus acquired an explicit non-nuclear dimension (Lohmann, 2015). US administrations under Clinton, Bush jr. and Obama gradually expanded the scope of the existing Iran sanctions regime by targeting ever more commercial activities of third countries in Iran. With the ISA scheduled to expire in late 2016 ('sunset' clause effective for 31 December), US Senators were pushing for a reauthorization of the Act (Demirjian, 2016a; 2016b). Such a reauthorization could fall under the US justification of 'sponsorship of terrorism', but would likely have been seen (not only) by Iran as breaching the spirit of the JCPOA. The ISA has been adopted for non-proliferation and anti-terrorism reasons, which possibly complicates its general termination. ${ }^{12}$ As economic sanctions, these are 
coercive measures. Coercion thus does not necessarily only mean physical transgressions in the form of military action, but also entails the intrusion into the conduct of economic relations of sovereign countries. In a Gramscian understanding, such an intrusive behavior is part and parcel of hegemonic strategy, because 'hegemony [is] protected by the armour of coercion' (Gramsci, 1971: 263).

Latest examples of unilateral US 'secondary' sanctions ${ }^{13}$ were the 2010 Comprehensive Iran Sanctions, Accountability, and Divestment Act (CISADA) sanctioning purchases of Iranian oil as well as business transactions with the Iranian Central Bank, ${ }^{14}$ the 2012 Iran Threat Reduction and Syria Human Rights Act, National Defense Authorization Act, and the Iran Freedom and Counter-Proliferation Act. Such a process of 'extraterritorialising' US legislation and enforcing political conceptions onto other states through compliance under the threat of economic costs is the epitome of coercion on the basis of the US predominance in the global trade, financial and economic system (see also Wilson, 2014: 202). The former high-level US officials Leverett \& Leverett (2013) even hold that US secondary sanctions are 'almost certainly' illegal under WTO regulations, but that no one has litigated the question so far (280). The Helms-Burton and D'Amato-Kennedy Acts, upon which CISADA was modelled, have been considered unlawful under international law (Dupont, 2012: 4; Lowe, 1997).

Yet, in order to pre-empt formal counter-action by EU member states in the WTO, the US government seemed to have found a modus operandi over the application 
of the ILSA. To this effect, it is worth quoting at length from Kenneth Katzman's (2006) CRS Report for Congress:

'Traditionally skeptical of economic sanctions as a policy tool, the European Union states opposed ILSA as an extraterritorial application of U.S. law. The EU countries threatened formal counter-action in the World Trade Organization (WTO), and in April 1997, the United States and the EU formally agreed to try to avoid a trade confrontation over ILSA (and a separate "Helms-Burton" Cuba sanctions law, P.L. 104-114). The agreement contributed to a decision by the Clinton Administration to waive ILSA sanctions on the first project determined to be in violation: a $\$ 2$ billion contract, signed in September 1997, for Total SA of France and its minority partners, Gazprom of Russia and Petronas of Malaysia to develop phases 2 and 3 of the 25-phase South Pars gas field. The Administration announced the "national interest" waiver (Section 9(c) of ILSA) on May 18, 1998, after the EU pledged to increase cooperation with the United States on non-proliferation and counter-terrorism. The announcement indicated that EU firms would likely receive waivers for future projects that were similar.'

Since 2010, however, US president Obama has enforced US unilateral sanctions also against European companies by way of executive orders (Lohmann, 2015). This aspect of extraterritoriality is unique to US unilateral sanctions. EU sanctions affect bilateral interactions with the sanctioned entity, but stop short of punishing third entities. 
'The fear of reputational costs', Giumelli \& Ivan (2013) write, 'has led banks to adopt cautious behavior in order to avoid paying the costs of defying UN, EU and especially US financial bans' (15). Costs can be in the form of denied access to US financial markets, loss of current accounts in US banks, or loss of US operating licences. 'Reputational costs' here underlines the perceived need to adhere to such a sanctions regime (out of fear of future consequences in the form of penalties) and forcefully ties in with the relational aspect of politics and the idea of internationalisation of dominant discourses.

At the same time, US financial threats (secondary sanctions, threats to exclude trading partners from US financial institutions) served to coerce other actors into acceptance of US policies. As explained above, Gramsci's conception of hegemony does not solely understand coercion as the use of armed force, but as the wider employment of instruments and policies to force actors into compliance. While the US had agreed to exclude European companies from US unilateral secondary sanctions at first, presidential executive orders under Obama as from 2010 affected European entities with full force again (Lohmann, 2015). 'We present our partners with a choice: You either trade with the Bank of Iran or you trade with the Bank of America,' former US National Security Council official and Woodrow Wilson scholar Robert Litwak bluntly stated in an interview (Author's interview, Washington, 31 October 2014). US legislation was being extraterritorialised. If a Foreign Financial Institution (FFI) trades 
in US dollars, it becomes subject to US jurisdiction. The sheer size of the US capital market and the fact that many of the biggest clearance banks operate in New York thus has introduced a powerful structural leverage to coerce both governments and private sector actors into compliance. Violations of US unilateral financial sanctions carry high penalties, and the fines levied against the French bank BNP Paribas in 2014 for having executed money transfers of companies, including Iranian ones, that are on US sanctions lists, was but the most recent and publicised example among a plethora of others (Lohmann, 2014: 6). The US Treasury imposed penalty payments on the British banks Lloyds, HSBC, Standard Chartered, Barclays, against Dutch ING and ABN Amro, against Swiss bank UBS and against the Royal Bank of Scotland (Lohmann, 2014; Taylor, 2010: 71). The declared intention is to change the behaviour of third parties, and the position of the US dollar as international reserve currency serves as the leverage to coerce other actors into succumbing to US policy preferences. In its global appeal and outreach ambition, this in essence is hegemonic behaviour.

\section{Transatlantic Strains after the Conclusion of a Nuclear Agreement}

2015 saw the end of the 12-year old nuclear odyssey with Iran. In part, this was made possible due to domestic changes in Iran and the US. A conciliatory Rouhani administration was met by an Obama administration willing to explore direct bilateral channels. The nuclear deal of 2015 presents chances and burdens associated with 
structural path dependencies in light of transatlantic Iran policies as discussed above. The nuclear agreement sealed on 14 July 2015, based on the parameters laid out in the political framework agreement of 2 April 2015 that had been reached in Lausanne, lays out conditions and mechanisms to ensure the exclusively peaceful nature of Iran's nuclear programme. It places restrictions on Iranian fuel-cycle activities for a duration of up to fifteen years, demands enhanced IAEA inspections at Iranian nuclear sites, and set up a Joint Commission with a dispute resolution mechanism to decide over any activities that may be deemed in contravention of the agreement. Iran commits itself to reduce its centrifuge numbers, restructure facilities such as the underground facility at Fordow and the heavy-water reactor at Arak, reduce its enriched uranium inventory to 300 kilograms and limit the enrichment level to 3.67 percent in accordance with the standard requirement for civilian nuclear power plants. In exchange for Iran honoring its terms of the agreement, sanctions imposed on Iran over its controversial nuclear programme are lifted. With the IAEA's stamp of approval regarding Iran's compliance with the agreement, the way was paved for the formal implementation of the agreement that saw the lifting of nuclear-related sanctions as well as the unlocking of previously frozen assets (JCPOA 2015).

The US administration had already announced the approval of waivers of unilateral nuclear-related Iran sanctions on Adoption Day, 18 October 2015. The lifting of unilateral sanctions makes inapplicable those parts of the ISA, the National Defense 
Authorization Act, the Iran Threat Reduction and Syria Human Rights Act, the Iran Freedom and Counter-Proliferation Act, the CISADA and a range of presidential executive orders that affected non-US persons and foreign financial institutions for dealings with Iranian entities sanctioned for nuclear-related reasons before. Likewise, the EU announced the lifting of its own unilateral nuclear-related sanctions (EU Council, 2015). Adoption Day, as defined in the JCPOA, came 90 days after the UN Security Council had endorsed the nuclear agreement in resolution 2231. Sanctions that included weapons embargoes, however, will be lifted after five years, and ballistic missile sanctions will be lifted after eight years. ${ }^{15}$ The JCPOA further states that US and EU unilateral sanction legislation will terminate after eight years at the latest. While nuclear-related sanctions were lifted in January 2016, the persistence of non-nuclearrelated US financial sanctions will continue to have extraterritorial effect on European entities. The US Treasury Department (2016: 32-33) has published guidelines clarifying the termination of executive orders pursuant to the JCPOA implementation. They also specify the lifting of nuclear-related secondary sanctions on Implementation Day, while noting that sanctions continue to apply to non-US persons and foreign financial institutes that 'facilitate [...] transactions or provide significant financial services for a person [...] blocked in connection with Iran's proliferation of WMD or their means of delivery (or that is) blocked in connection with Iran's support for international terrorism' (9). And it is the latter prospect that constitutes a source of friction for US 
and EU future Iran policies.

European companies have been eagerly awaiting the end of sanctions, hoping to re-enter the Iranian market and thereby rejuvenate European-Iranian trade relations. The lifting of nuclear-related sanctions was a precondition for such a scenario. The 'new chapter' in relations with Iran that Mogherini's and Zarif's joint statement of 14 July 2015 refers to can be read in different lights depending on the actor's perspective. Iranian and European companies and most governments hope for new business opportunities. The German company Siemens, the oil company Shell, and French automobile manufacturers like Peugeot and Renault already indicated their interest in exploring investment opportunities in Iran (Nirumand, 2015: 12). German vicechancellor and Economy Minister Sigmar Gabriel travelled to Iran on 19 July 2015, just days after the conclusion of the nuclear agreement as the first European high-level minister, followed by French foreign minister Laurent Fabius on 29 July. Mogherini traveled to Iran on $28 \mathrm{July}$, and announced that 'we want cooperation instead of confrontation in all areas' (Nirumand, 2015: 18). The nuclear agreement, she let it be known, is not the end, but the beginning of a new chapter in EU-Iran relations. With sanctions lifted, Iran would be able to increase the production and export of oil. This is a prospect that European actors are exploring with interest: The rapid deterioration in relations between Russia and the EU in the course of the Ukraine crisis has sped up Europe's efforts to diversify its energy sources away from Russia (European 
Commission, 2015; ECFR, 2015). But also Russia is seeking to diversify its oil and gas customers and increasingly seeks to export LNG to the Asian market (Westphal, 2014). While the prospect of Iran becoming an important energy supplier for Europe is still unclear, it cannot be excluded that political dynamics have the potential to shake Russia's position on the European energy market and hasten European ambitions to develop closer energy ties to Iran (cf. also Sasnal \& Secrieru, 2015).

With a deal negotiated, commercial incentives can create a path dependency that makes the re-imposition of sanctions in case of Iranian violation of the agreement more unlikely despite the 'snapback' mechanism foreseen under the JCPOA. In a historical institutionalist perspective, unintended consequences reduce policy leeway (Hay and Wincott, 1998: 952). The lifting of Iran sanctions reverses this logic: The intended consequences of the JCPOA ('new chapter in relations with Iran') reduce the leeway of governments to re-impose sanctions. The complex web of sanctions woven by US administrations, however, means that the lifting of US nuclear-related sanctions will not affect sanctions that were imposed over human rights violations and terrorism charges. It was this expectation that Ayatollah Khamenei hinted at in his statement endorsing the nuclear agreement. In it, he demanded that all 'economic and financial sanctions' on the part of the US and the EU be lifted if Iran meets its terms of the agreement (Erdbrink 2015). The US, however, will retain secondary sanctions targeting third parties 'for dealings with Iranian persons on our SDN list, including those designated under our 
terrorism, counter-proliferation, missile, and human rights authorities.' Such parties would 'put themselves at risk of being cut off from the U.S. financial system. This includes foreign financial institutions, who would risk losing their correspondent account with U.S. banks' (White House, 2015). Complicating matters for companies eager to invest in Iran is the extent to which Iranian companies control relevant parts of the economy that will continue to fall into the above categories. Examples here are banks listed for carrying out terrorism-related transactions; construction, trading and transport companies tied to the IRGC; or telecommunication companies (Kagan, 2015). Richard Nephew, former Principal Deputy Coordinator for Sanctions Policy at the US State Department, therefore advises companies to 'develop clear force majeure clauses and other schemes to insure themselves against the risk of immediate sanctions reapplication' (Nephew, 2015: 3). As Mark Fitzpatrick, former US State Department official, remarks: '[The] absence of reliable banking channels means other businesses will have no way to repatriate profits' (Fitzpatrick, 2016). Companies and banks are requested to exercise 'due diligence' when engaging with Iranian entities and remain cautious about exploring new opportunities. US structural power in international financial mechanisms will continue to dangle a Damocles sword over any European activities in Iran - regardless of the formal lifting of nuclear sanctions. As long as firms have connections to the capital market of the United States, their Iran business can be subject to financial penalties. Access to the US capital market is a powerful leverage to 
coerce actors into compliance.

Ultimately, it will remain a political decision of historic dimensions to unravel enemy narratives that have been created over decades. Irrespective of the implementation of the JCPOA, the persistence of such narratives ensures the US monopoly over the interpretation of normative standards in World Order by definitional fiat. As long as the US establishment (i.e., including US influential think tanks, media pundits, and Iran-sceptical parts of US Congress) are opposed to any rapprochement with Iran, the nuclear agreement may remain a policy-specific (i.e., non-proliferation) document without the 'fundamental shift' in approach that Federica Mogherini and Javad Zarif proudly announced upon the conclusion of the JCPOA in July 2015 (EEAS, 2015). Short of a transformational nature of the agreement, multilateral benefits would remain transactional. However, issue-specific coordination of policies, such as the fight against the so-called Islamic State, that had hitherto been conditioned on an agreement on the nuclear programme, would now become a possibility as the implementation of the agreement proceeds. But also the future of Iraq, security in the Persian Gulf, the status of religious minorities, and negotiations about a Nuclear Weapon-Free Zone in the Middle East could and should be discussed with Iran now that the nuclear dispute does not consume the main bulk of diplomatic resources anymore. A new engagement with Iran after the nuclear deal could 'eventually facilitate the creation of an inclusive security governance structure in the Gulf', as Riccardo Alcaro formulates (2015: 3; see 
also Alcaro, 2013: 94). Officially, however, all state parties to the nuclear agreement continue to uphold the policy of separating other policy domains from the nuclear dossier (Barzegar, 2014: 5). The implementation of the JCPOA is therefore a long-term process. Until 2025, Iran will be subject to a special monitoring and inspection regime and only then be treated as any other non-nuclear weapon state (NNWS) under the Nuclear Non-Proliferation Treaty (NPT). While EU and US unilateral economic sanctions imposed over the nuclear programme are lifted, as are UNSC-mandated sanctions, the 'snap back' of sanctions is still an option that E3+3 states have kept at their disposal in case of Iranian non-compliance with its terms of the agreement. Sanctions provisions in those UNSCR superseded by the UNSCR 2231 which endorsed the JCPOA would be re-imposed in such a scenario. Actors sceptical of Iranian good faith can flag the 'justified suspicion' principle in arguing for continued restraint in normalising relations with Iran. US terrorism and human rights-related sanctions continue to serve the same purpose of perpetuating the narrative woven around the need to securitise Iran. The intensification of broader economic ties that also many European states hope for could therefore still be threatened with powerful financial sanctions leverage, both targeted and extraterritorial. The EU's contribution in Iran diplomacy could lie in 'compartmentalizing and de-politicizing' cooperation with Iran, as Adebahr contends (2015a). The European Union's ability to compensate for an earlier loss of agency as described in the first part of this article is conditioned on a re-balancing of 
transatlantic relations. This would require the questioning of a hegemonic consent as outlined above. It would also require the build-up of EU institutional support and capacities that would free up resources for a more comprehensive and strategic policy planning on Iran beyond the technical nuclear file (Adebahr, 2015b; Alcaro \& Tabrizi, 2014: 20). However, with the applicability of US financial sanctions exercising a structural force that national European governments hardly have instruments to circumvent, it will remain a major quasi-ideological question how cooperation with Iran can take shape as the nuclear agreement will be gradually implemented. As long as EU administrations tie their foreign policies to US policy preferences, an emancipation of European Iran policies remains a distant vision. Emancipatory policies would empower European actors (state and non-state alike) to challenge legally discriminatory regimes adopted and sustained for political reasons. Such a contestation of power relations would gradually work to deconstruct consensual narratives that constitute a foundational pillar in hegemonic arrangements. This would amount to the shaking off of 'attitudes, behaviours, and strategies [that EU member states] acquired over decades of American hegemony' and to 'the emergence of a post-American Europe' that Shapiro and Witney $(2009,7)$ have worked out as a condition for a new transatlantic relationship (see also Kempin \& Mawdsley, 2013: 56). It would also require a critical examination of the 'sanctions paradox' according to which policymakers continue to invoke such instruments despite questionable effects on 'target' actors (Taylor, 2010: 16). Taylor 
(2010) argues that the actual goal of 'great-power policymakers $[\ldots]$ is often to influence one another in the context of executing and advancing their respective grand strategies' (15). Devising new narratives as the Iran sanctions architecture unravels in the aftermath of the JCPOA involves contesting such automatisms within 'coalitions of concerned' (Taylor, 2010: 99). At stake is not only the future of Iran's regional standing, but the resolution of transatlantic disagreements over the Middle East, and over the nature of the US-EU relationship. After the conclusion of the JCPOA, Mogherini expressed pride in the work of the European negotiation team in the European External Action Service (EEAS) and the EU's contribution to the Iran deal (Mogherini, 2015). This assessment was broadly shared by the various other actors involved in the talks. Russian deputy foreign minister Sergei Ryabkov acknowledged the European contribution in an interview as follows: 'The role of the EU and of the European External Action Service is hard to exaggerate; they coordinated the talks, they summarised the outcome of the discussions, and in fact they were the ones essentially drafting the text, together with Iranian representatives' (CENESS, 2015: 11). Beyond the level of technical talks expertly conducted under the chairmanship of the nuclear negotiation team of the EEAS, however, there has been no conceptualisation about regional policies and relations with Iran after the conclusion of a nuclear agreement thus far. 


\section{Conclusion}

This article has shown how the European Union initially was in the driver's seat when a hitherto unknown Iranian nuclear programme was uncovered in 2002. After the extension of the negotiating format to the $\mathrm{P} 5+1$ in 2006 , and the inclusion of the United States, Europe took a back seat, while the US government began to table sanctions resolutions. European governments involved in Iran diplomacy gradually adapted their positions to allow for a closer policy alignment with American positions after the failure of the November 2004 agreement, and all the more in the extended E3+3 format as from 2006. Once sanctions began to be imposed, European governments started to 'overcomply' in their implementation of UNSCR sanctions as from 2007, and adopted their own sanctions after 2010 that had an impact that was much stronger on the Iranian economy than US sanctions had. In addition, European entities were targeted in the wake of the adoption of US unilateral (financial) sanctions that had an extraterritorial effect. The stated aim on the part of the US government was to discourage interactions with the originally targeted country (Iran), thus inducing policy changes. NeoGramscian scholarship helped shed light on such a strategy which was conceptualised as that of global hegemonic structures exercising coercion through the implementation of financial instruments on the basis of the dominant position of the United States in international financial governance. Yet, coercive domination alone cannot sustain such 
hegemonic structures, thus necessitating consensual arrangements to legitimise narratives of enemy projection. The track record of EU 'compliance' with these structural forces has shown how a 'transatlantic dialogue' deprived Europe of autonomous policy-making, as the EU consciously shifted from (implicit) critique to endorsement. The most important actor in deciding over Iran's nuclear future during the decade of nuclear diplomacy was the US. The EU's diplomacy, however, acquired new relevance after the 2009 Lisbon Treaty that saw the setting-up of the European External Action Service. The EEAS was at the helm of the nuclear talks in the years leading up to the diplomatic success that marked the signing of the JCPOA in July 2015. The EEAS facilitated, coordinated and chaired the nuclear talks, and the European contribution to this diplomatic dossier has been widely acknowledged as being critical to the success of the negotiations.

With the conclusion of a Joint Comprehensive Plan of Action in Vienna on 14 July 2015, however, the EU-US dialogue on Iran is set to undergo shifts, if not outright policy changes if EU-Iran relations are to be lifted to some altered level beyond the technical negotiations about the Iranian nuclear programme. After the negotiation phase, the formulation of new Iran policies in Europe is partly conditioned on a disengagement from what Gramsci called a 'historic bloc' whose consent helps to sustain dominant power relations. This means nothing less than a re-balancing of the 'transatlantic element' in Western-Iranian relations. A European emancipation from US Iran policies 
would give back not only breathing space for European commercial activities, but would also allow the conceptualisation of regional policies beyond the Iranian nuclear file (Alcaro, 2015). This development might have the potential to lead to the formulation of new European Middle Eastern policies, and to test European 'actorness' on the global stage. The lifting of nuclear-related Iran sanctions that marked the implementation of the JCPOA in January 2016 was only the first step in this direction.

\section{Notes}

\footnotetext{
${ }^{1}$ However, some restrictions related to nuclear-, conventional arms-, and ballistic missile-related activities apply under UNSCR 2231 of 20 July 2015, which has endorsed the JCPOA. See US Department of the Treasury (2016: 2).

${ }^{2}$ Mark Fitzpatrick (2006a) writes that even before the birth of the P5+1 format in 2005/2006, US Under Secretary for Political Affairs Nicholas Burns had 'consulted closely with his EU-3 counterparts and joined strategy session' (73). From the beginning, thus, the US was involved in the process, but not yet at the forefront of diplomatic activity. Fitzpatrick (2006a) also confirms that Russia and China were sometimes included in these sessions before the P5+1 format existed.

${ }^{3}$ David O'Sullivan, EEAS Chief Operating Officer, therefore remarked with regard to the difficult approximations of different national positions that an E3 line usually provides a good indicator for an EUwide compromise. Keynote speech at the EXACT conference, Brussels, 11 July 2013.

${ }^{4}$ Examples include Borda (2005); Dryburgh (2008); Fischer (2011: 250f.); Sauer (2007, 2015); Straw (2012: 433f.); Tertrais (2006); Giumelli \& Ivan (2013); Kuzmicheva (2009); Peimani (2006); Keukeleire \& MacNaughtan (2008: 113); Bretherton \& Vogler (2006: 183); Kile (2005); Ansari (2006: 202f.); Barzegar (2012: 255f.); Patrikarakos (2012: 195-225); Mousavian (2012); Chirac (2011: 300).

${ }^{5}$ Former British Foreign Secretary Jack Straw (2012) recounts in his memoirs how in this early phase of negotiations over nuclear Iran, the US was highly suspicious of not only the Iranians, but also of the Europeans' approach (405; 448; 453). Tellingly, former US Defense Secretary Donald Rumsfeld (2011) calls E3 diplomacy with Iran a 'disaster' in his memoirs (639). And former Iranian nuclear spokesperson Mousavian (2014) suspected US behind-the-scene activities in the E3' lack of flexibility in 2003-2005 (202-206).

${ }^{6}$ The measures included restrictions on trade and investment in the Iranian insurance, banking, transportation and energy sector.

${ }^{7} \mathrm{EU}$ unilateral sanctions have been applied to more sectors, including non-proliferation, and moved from 'targeted' to arguably comprehensive sanctions approaches. Yet, the intended effects and likely impact of EU sanctions lacks both public and governmental scrutiny (as admitted by government officials. EU sanctions workshop, 14 May 2015, London.). Cf. also Portela (2010).
} 


\footnotetext{
${ }^{8}$ While 'bankrupting' a country is not the aim of any sanctions regime - at least not overtly - this interviewee's snide remark gives an indication of the power of path dependency once a multilateral sanctions momentum gains traction.

${ }^{9}$ Suffice to recall the important caveat that 'the EU's Iran policy' is the outcome of consultation and coordination among the 'E3' with their partially conflicting respective preferences, together with the nuclear negotiation team of the EEAS under the lead chairmanship of the Union's High Representative for Foreign and Security Policies.

${ }^{10}$ Note that this consensus relates to the governmental level. A private sector representative remarked that the US State Department had been anxious of the European Court of Justice being too interventionist with regard to unilateral sanctions legislation, as a number of case challenging the legality of targeted sanctions against entities or individuals have been successful before the ECJ. While there is often a lack of evidentiary standards and due process, the US government's position has been that "they like the legal uncertainty because it often leads to over-compliance." EU Sanctions workshop under Chatham House rules, 14 May 2015, London.

${ }^{11} \mathrm{ABC}$ weapons are understood as atomic, biological, chemical or radiological weapons - commonly also referred to as 'weapons of mass destruction' (WMD).

${ }^{12}$ The president, however, can still waive sanctions on a case-by-case basis if he determines it is 'essential to national security interests'.

${ }^{13}$ These are called 'secondary' because they do not stop at sanctioning the target state directly, but also aim to punish third country entities' dealings with the target state.

${ }^{14}$ CISADA also included sanctions against the sale of Iranian caviar, carpets and pistachios, which had previously been exempted under the Clinton administration.

${ }^{15}$ New US financial sanctions against 11 entities related to Iranian ballistic missile tests were adopted just one day after the lifting of nuclear-related sanctions (BBC 2016).
}

\section{References}

Adebahr C (2015a) Leave it to Europe: Why Iran Is Not (Solely) America's Responsibility. The National Interest, 8 June. Available at: http://nationalinterest.org/feature/leave-it-europe-why-iran-not-solelyamericas-responsibility13057?page $=2 \&$ mkt tok=3RkMMJWWfF9wsRojva3BZKXonjHpfsX64u8rU KCg38431UFwdcjKPmjr1YYDRcp0aPyQAgobGp5I5FEIQ7XYTLB2t60MW A\%3D\%3D (accessed 25 April 2015).

Adebahr C (2015b) Shaping EU-Iran Relations Beyond the Nuclear Deal. Carnegie Oped, 25 August. Available at:

http://carnegieendowment.org/2015/08/25/shaping-eu-iran-relations-beyondnucleardeal/if86?mkt tok=3RkMMJWWfF9wsRogvanLZKXonjHpfsX64u8rUKCg38 431UFwdcjKPmjr1YUCTMd0aPyQAgobGp5I5FEIQ7XYTLB2t60MWA\%3 D\%3D (accessed 13 November 2015).

Afrasiabi K and Kibaroğlu M (2005) Negotiating Iran's Nuclear Populism. Brown Journal of World Affairs 12(1): 1-17. 
Alcaro R (2013) Friends and Foes of a United States-Iran Nuclear Agreement. Turkish Policy Quarterly 12(3): 93-101.

Alcaro R (2015) The West and the Middle East After the Iran Nuclear Deal. Istituto Affari Internazionali Working Papers 15, July 2015.

Alcaro R and Tabrizi AB (2014) Europe and Iran's Nuclear Issue: The Labours and Sorrows of a Supporting Actor. The International Spectator 49(3): 14-20.

Ansari A (2006) Confronting Iran. The Failure of American Foreign Policy and the Next Great Conflict in the Middle East. New York: Basic Books.

Bacevich A J (2002) American Empire. The Realities \& Consequences of U.S. Diplomacy. Cambridge/London: Harvard University Press.

Barzegar K (2012) Iran's Nuclear Program. In: Kamrava M (ed.) The Nuclear Question in the Middle East. New York: Columbia University Press, pp. 225-264.

Barzegar K (2014) Iran-US Relations in the Light of the Nuclear Negotiations. The International Spectator 49(3): 1-7.

BBC (2016) Iran condemns new US sanctions over missile test. Middle East News, 18 January. Available at: http://www.bbc.co.uk/news/world-middle-east35340663?mkt tok=3RkMMJWWfF9wsRous6XNZKXonjHpfsX64u8rUKCg 38431UFwdcjKPmjr1YsGTst0aPyQAgobGp5I5FEIQ7XYTLB2t60MWA\%3 D\%3D (accessed 25 February 2016).

Beach D and Pedersen, R B (2013) Process Tracing Methods: Foundations and Guidelines. Michigan: University of Michigan Press.

Biersteker T and Moret E (2015) Rising powers and reform of the practices of international security institutions. In: Gaskarth, J (ed.), Rising Powers, Global Governance and Global Ethics. Abingdon and New York: Routledge, pp. 5773.

Bretherton C and Vogler J (2006) The European Union as a Global Actor. $2^{\text {nd }}$ edition. New York: Routledge.

Bromley S (2004) American power and the future of international order. In: Brown W, Bromley S and Athreye S (eds.) A world of Whose Making? Ordering the International: History, Change and Transformation, eds. Brown, William, Bromley, Simon and Athreye, Suma. London: Pluto Press, pp. 145-182.

Center for Energy and Security Studies (2015) The Iran Nuclear Deal: Russia's Interests and Prospects for Implementation. 14 August. Transcript of a Meeting with Russian Deputy Foreign Minister Sergey Ryabkov. Available at: http://cenessrussia.org/data/page/p1494_1.pdf?mkt_tok=3RkMMJWWfF9wsRogvazKZKX 
onjHpfsX64u8rUKCg38431UFwdcjKPmjr1YUDScd0aPyQAgobGp5I5FEIQ7 XYTLB2t60MWA\%3D\%3D (accessed 2 September 2015).

Chirac J (2011) My Life in Politics. Transl. by Spencer, Catherine. New York: Palgrave Macmillan.

Chomsky N (1992) A View from Below. In: Hogan, M J (ed.) The End of the Cold War. Its Meaning and Implications. Cambridge: Cambridge University Press, pp. $137-150$.

Chomsky N (2003) Hegemony or Survival. America's Quest for Global Dominance. London: Penguin Books.

Cox M (2001) Whatever happened to American decline? International Relations and the new United States hegemony. New Political Economy 6(3): 311-340.

Cox M (2007) Is the United States in decline - again? An Essay. International Affairs 83(4): 643-653.

Cox R W (1981) Social Forces, States and World Orders: Beyond International Relations Theory. Millennium: Journal of International Studies 10(2): 126155.

Cox R W (1996) Approaches to World Order. Cambridge: Cambridge University Press.

Demirjian K (2016) With Iran nuclear deal in place, key senators look to slap new sanctions on country. PowerPost. The Washington Post, 2 February. Available at: https://www.washingtonpost.com/news/powerpost/wp/2016/02/02/withiran-nuclear-deal-in-place-key-senators-look-to-slap-new-sanctions-oniran/?mkt_tok=3RkMMJWWfF9wsRovuq\%2FPZKXonjHpfsX64u8rUKCg38 431UFwdcjKPmjr1YsISct0aPyQAgobGp5I5FEIQ7XYTLB2t60MWA\%3D\%3 D (accessed 25 February 2016).

Demirjian K (2016) Corker has a new Iran sanctions bill, but more bipartisan support may be hard to come by. PowerPost, The Washington Post, 13 July. Available at: https://www.washingtonpost.com/news/powerpost/wp/2016/07/13/corkerhas-a-new-iran-sanctions-bill-but-bipartisan-support-will-be-hard-to-comeby/?mkt_tok=eyJpIjoiTIRsbE5UTmhaRGMwTURFdyIsInQiOiJsWDZqRHRh TG84SklsMnJxQUV6XC9CNU12MGIrcyt0UUdsQ2orMFUwN0FOZ1wvU1J KZ1ZrMjg2eUVvVXVLWmNxc3ZcL3d4WjE2akR6SzA0RW9sMlpGT0tXW HRFNFMzTzRvMko4TVpUQkJaRkhlRT0ifQ\%3D\%3D (accessed 18 July 2016).

Dryburgh L (2008) The EU as a Global Actor? EU Policy Towards Iran. European Security 17(2/3): 253-271.

Dupont P (2012) Countermeasures and Collective Security: The Case of the EU Sanctions Against Iran. Journal of Conflict and Security Law 17(3): 301-336. 
EEAS (2015) Joint statement by EU High Representative Federica Mogherini and Iranian Foreign Minister Javad Zarif Vienna, Press statement, 14 July.

Available at: http://www.eeas.europa.eu/statementseeas/2015/150714_01_en.htm (accessed 13 August 2015).

Erdbrink T (2015) Iran Nuclear Deal Wins Tepid Endorsement From Ayatollah Ali Khamenei. The New York Times, 21 October. Available at: http://www.nytimes.com/2015/10/22/world/middleeast/iran-nuclear-dealayatollah-alikhamenei.html?mkt tok=3RkMMJWWfF9wsRohva7JZKXonjHpfsX64u8rUK Cg38431UFwdcjKPmjr1YQCScp0aPyQAgobGp5I5FEIQ7XYTLB2t60MWA \%3D\%3D\&_r=0 (accessed 13 November 2015).

EU Council (2010) Council Regulation (EU) No 961/2010 of 25 October 2010 on restrictive measures against Iran and repealing Regulation 423/2007. Available at: http://eurlex.europa.eu/LexUriServ/LexUriServ.do?uri=OJ:L:2010:281:0001:0077:EN:PDF (accessed 16 September 2016).

EU Council (2012a) Council Decision 2012/35/CFSP of 23 January 2012 amending Decision 2010/413/CFSP concerning restrictive measures against Iran. Available at: http://eur-lex.europa.eu/legalcontent/EN/TXT/?uri=CELEX\%3A32012D0035 (accessed 16 September 2016).

EU Council (2012b) Council Regulation No 267/2012 of 23 March 2012 concerning restrictive measures against Iran and repealing Regulation (EU) 961/2010. Available at: http://eur-lex.europa.eu/legal-

content/EN/TXT/?uri=uriserv:OJ.L .2012.088.01.0001.01.ENG\&toc=OJ:L:2012:088: TOC (accessed 16 September 2016).

EU Council (2012c) Council Decision 2012/635/CFSP of 15 October 2012 amending Council Decision 2010/413/CFSP concerning restrictive measures against Iran. Available at: http://eurlex.europa.eu/LexUriServ/LexUriServ.do?uri=OJ:L:2012:282:0058:0069:EN:P DF (accessed 16 September 2016).

EU Council (2015) Iran nuclear deal: Council adopts the legal acts to prepare for the lifting of all nuclear-related economic and financial EU sanctions. Press Release, 18 October. Available at: http://www.consilium.europa.eu/en/press/press-releases/2015/10/18-irannuclear-deal/ (accessed 26 February 2016).

European Commission (2015) Energy Union Package. Communication from the European Commission to the European Parliament, the Council, the European Economic and Social Committee, the Committee of the Regions and the 
European Investment Bank: A Framework Strategy for a Resilient Energy Union with a Forward-Looking Climate Change Policy. European Commission Communication $\operatorname{COM}(2015)$ 80, 25 February. Available at:

http://ec.europa.eu/priorities/energy-union/docs/energyunion_en.pdf (accessed 13 April 2015).

European Council on Foreign Relations (2015) Europe's alternatives to Russian gas. Article, 9 April. Available at:

http://www.ecfr.eu/article/commentary_europes_alternatives_to_russian_gas31 1666. (accessed 13 April 2015).

Fischer J (2011) 'I am not convinced'. Der Irak-Krieg und die rot-grünen Jahre. Köln: Kiepenhauer \& Witsch.

Fitzpatrick M (2006a) Iran and North Korea: The Proliferation Nexus. Survival 48(1): 61-80.

Fitzpatrick M (2016) The Iran deal shows its worth. Politics and Strategy, the Survival Editors' Blog, 18 January. Available at: https://www.iiss.org/en/politics\%20and\%20strategy/blogsections/2016d1f9/january-c129/the-iran-deal-shows-its-worth-ded4 (accessed 2 March 2016).

Giumelli F and Ivan P (2013) The effectiveness of EU sanctions. An analysis of Iran, Belarus, Syria and Myanmar (Burma). EPC Issue Paper No. 76.

Gramsci A (1971) Selections from the Prison Notebooks, ed. and trans. Hoare, Q. London: Lawrence \& Wishart.

Hart AF and Jones BD (2011) How Do Rising Powers Rise? Survival 52(6): 63-88.

Hay C and Wincott D (1998) Structure, Agency and Historical Institutionalism. Political Studies XLVI: 951-957.

Homolar A (2011) Rebels without a Conscience: The Evolution of the Rogue States Narrative in US Security Policy. European Journal of International Relations 17(4): 705-27.

Hoyt PD (2000) The 'Rogue State' Image in American Foreign Policy. Global Society 14(2): 297-310.

IAEA (2016) Verification and Monitoring in the Islamic Republic of Iran in light of United Nations Security Council Resolution 2231 (2015). IAEA board report, 16 January 2016. Available at: https://www.iaea.org/sites/default/files/gov2015-53.pdf (accessed 6 September 2016).

Ikenberry J G (2004) Liberalism and Empire: Logics of Order in the American Unipolar Age. Review of International Studies 30(4): 609-30. 
Joint Comprehensive Plan of Action (2015) 14 July. Available at: https://eeas.europa.eu/statements-eeas/docs/iran_agreement/iran_jointcomprehensive-plan-of-action_en.pdf (accessed 21 July 2016).

Jones S (2006) Antonio Gramsci. Abingdon: Routledge.

Kagan F W (2015) Complexities of Iranian sanctions relief. American Enterprise Institute, Article, 3 April. Available at: https://www.aei.org/publication/complexities-of-iranian-sanctions-relief/ (accessed 26 February 2016).

Katzman K (2006) The Iran-Libya Sanctions Act (ILSA). CRS Report for Congress, 26 April. Available at: http://fpc.state.gov/documents/organization/66441.pdf. (accessed 27 September 2014).

Kempin R and Mawdsley J (2013) The Common Security and Defence Policy as an act of American hegemony. European Security 22(1): 55-73.

Keukeleire S and MacNaughtan J (2008) The Foreign Policy of the European Union. Basingstoke: Palgrave MacMillan.

Kile S N (2005) Europe and Iran: Perspectives on Non-Proliferation. Oxford: Oxford University Press.

Koutzias N and Liacouras P (eds.) (2006) EU-US Relations. Repairing the Transatlantic Rift. Basingstoke: Palgrave Macmillan.

Krahmann E (2005) American Hegemony or Global Governance? Competing Visions of International Security. International Studies Review 7(4): 531-545.

Kuzmicheva L (2009) EU Foreign Policies in the Middle East- Iran, Iraq, Syria, IsraeliPalestinian Peace Process. Woodrow Wilson International Center for Scholars.

Layne C (2006) The Peace of Illusions. American Grand Strategy from 1940 to the Present. New York: Cornell University Press.

Lee L (2010) US Hegemony and International Legitimacy: Norms, Power and Followership in the Wars in Iraq. London: Routledge.

Lehne S (2012) The Role of Sanctions in EU Foreign Policy. Carnegie Article, 14 December 2012. Available at: http://carnegieeurope.eu/publications/?fa=50378 (accessed 2 September 2015).

Leverett F and Leverett H M (2013) Going to Tehran. Why the United States Must Come to Terms with the Islamic Republic of Iran. New York: Metropolitan Books.

Lohmann S (2013) Unilaterale US-Sanktionen gegen Iran. SWP-Aktuell 63: 1-8.

Lohmann S (2014) Minenfelder der US-Außenwirtschaftspolitik. Unilaterale Finanzsanktionen im Dienst nationaler Sicherheit. SWP-Aktuell 71: 1-8. 
Lohmann S (2015) Zwang zur Zusammenarbeit. SWP-Aktuell 54: 1-8.

Lowe V (1997) US Extraterritorial Jurisdiction: The Helms-burton and D'Amato Acts. International and Comparative Law Quarterly 46(2): 378-390.

Menotti R and Vencato MF (2008) The European Security Stragegy and the partners. In: Biscop S and Andersson JJ (eds.), The EU and the European Security Strategy. Forging a global Europe. Abingdon: Routledge, pp. 103-121.

Mogherini F (2015) Mogherini proud of EU contribution to Iranian deal. Statement, 15 July. Available at: http://eeas.europa.eu/top_stories/2015/150715_irandeal_en.htm. (accessed 13 August 2015).

Mousavian S H (2012) The Iranian Nuclear Crisis. A Memoir. Washington: Carnegie Endowment for International Peace.

Mousavian S H (with Shahir Shahidsaless) (2014) Iran and the United States. An Insider's View on the Failed Past and the Road to Peace. New York, London: Bloomsbury.

Narlikar A (2013) Introduction. Negotiating the rise of new powers. International Affairs 89(3): 561-576.

Nephew R (2015) Commentary on the Nuclear Deal Between Iran and the P5+1. Center on Global Energy Policy, Columbia University. Commentary, 14 July.

Available at:

http://energypolicy.columbia.edu/sites/default/files/energy/Commentary\%20on \%20the \%20Nuclear\%20Deal\%20between\%20Iran\%20and\%20the\%20P5\%2B 1.pdf. (accessed 26 February 2016).

Nirumand B (2015) Iran-Report 08/15. Heinrich-Böll Stiftung. Available at: https://www.boell.de/de/2015/08/05/iran-report-082015 (accessed 20 August 2015).

Oborne P and Morrison D (2013) A dangerous delusion. Why the West is wrong about nuclear Iran. London: Elliot and Thompson Limited.

Patrikarakos D (2012) Nuclear Iran. The Birth of an Atomic State. London, New York: I.B. Tauris.

Peimani H (2006) The EU and US Policies towards Iran: Common Objectives and Different Approaches. In: Bono G (ed.), The Impact of 9/11 on European Foreign and Security Policy. Brussels: VUB Press, chap. 10.

Pieper M (2014) Chinese, Russian, and Turkish Policies in the Iranian Nuclear Dossier: Between Resistance to Hegemony and Hegemonic Accommodation. Asian Journal of Peacebuilding 2(1): 17-36. 
Pieper M (2017, forthcoming) Hegemony and Resistance around the Iranian Nuclear Programme: Analysing Chinese, Russian and Turkish Foreign Policies. London: Routledge.

Portela C (2010) European Union Sanctions and Foreign Policy: When and Why Do They Work? London: Routledge.

Porter G (2014) Manufactured Crisis. The Untold Story of the Iran Nuclear Scare. Charlottesville: Just World Books.

Quinn A (2011) The art of declining politely: Obama's prudent presidency and the waning of American power. International Affairs 87(4): 803-824.

Rees W (2011) The US-EU Security Relationship. The Tensions between a European and a Global Agenda. Basingstoke: Palgrave Macmillan.

Robinson W I (1996) Promoting Polyarchy: Globalization, US Intervention, and Hegemony. Cambridge: Cambridge University Press.

Rumsfeld D (2011) Known and Unknown. A Memoir. London: Sentinel.

Sasnal P and Secrieru S (2015) Out of the Comfort Zone: Russia and the Nuclear Deal with Iran. Strategic File, No. 11 (74), June 2015. Warsaw: The Polish Institute of International Affairs.

Sauer T (2007) Coercive Diplomacy by the EU: The Iranian Nuclear Weapons Crisis. Third World Quarterly 28(3): 613-633.

Sauer T (2015) The EU as a Coercive Diplomatic Actor? The EU-3 Initiative towards Iran. In: Koops J A and Macaj G (eds.), The European Union as a Diplomatic Actor. Basingstoke: Palgrave Macmillan, pp. 103-119.

Senn M (2009) Wolves in the Woods. The Rogue State Concept from a Constructivist Perspective. Baden-Baden: Nomos.

Shapiro J and Witney N (2009) Towards a Post-American Europe: a power audit of EU-US Relations. European Council on Foreign Relations, October 2009.

Stokes D (2005) America's Other War. Terrorizing Colombia. London/ New York: Zed Books.

Stokes D (2014) Achilles' deal: Dollar decline and US grand strategy after the crisis. Review of International Political Economy 21(5): 1071-1094.

Straw J (2012) Last Man Standing. Memoirs of a Political Survivor. London: Pan Books.

Tabrizi, AB (2014) The EU's Sanctions Regime against Iran in the aftermath of the JPA. European Council on Foreign Relations, June 2014.

Tabrizi AB and Santini RH (2012) EU Sanctions against Iran: new wine in old bottles? ISPI Analysis, No. 97, March 2012. 
Takeyh R and Maloney S (2011) The self-limiting success of Iran sanctions. International Affairs 87(6): 1287-1312.

Taylor B (2010) Sanctions as Grand Strategy. Adelphi series, International Institute for Strategic Studies. Abingdon: Routledge.

Tertrais B (2006) The Iranian Nuclear Crisis. In: Daalder I, Gnesotto N and Gordon P (eds.), Crescent of Crisis. US-European Security for the Greater Middle East. Washington: Brookings Institution, pp. 25-40.

Toje A (2008) America, the EU and Strategic Culture. Renegotiating the Transatlantic Bargain. New York: Routledge.

US Department of the Treasury (2016) Guidance relating to the lifting of certain U.S. sanctions pursuant to the Joint Comprehensive Plan of Action on Implementation Day. 16 January.

Westphal K (2014) Russland und Europas Energiemix. Krim-Krise: Abhängigkeiten und Strategien. Energlobe, 20 March. Available at:

http://energlobe.de/politik/krim-krise-abhaengigkeiten-und-strategienrussland-und-europas-energiemix (accessed 13 April 2015).

White House (2015) The Iran Nuclear Deal : What You Need To Know About The JCPOA. Information Sheet. Available at: https://www.whitehouse.gov/sites/default/files/docs/jcpoa_what_you_need_to know.pdf (accessed 26 February 2016).

Wicht B (2002) Guerre et Hégémonie. L'éclairage de la longue durée. Paris: Georg Editeur.

Wilkinson D (1999) Unipolarity without Hegemony. International Studies Review 1(2): 141-172.

Worth O (2009) Beyond world order and transnational classes. The (re)application of Gramsci in global politics. In: McNally M and Schwarzmantel J (eds) Gramsci and global politics: hegemony and resistance. London and New York: Routledge, pp. 19-31.

Worth O (2011) Recasting Gramsci in international politics. Review of International Studies 37(1): 373-392. 